\title{
Overview on Polyhydroxyalkanoates: A Promising Biopol
}

Varsha $\mathbf{Y M}^{*}$ and Savitha $\mathbf{R}$

School of Chemical and Biotechnology, SASTRA University, India

\begin{abstract}
Plastic pollution is creating the significant environmental and economic burdens since they consume the natural fuels (energy) and other natural resources. Beside this, they have long shelf time, debasing the environment in the numerous ways. The only way to trim down the hazards of plastic pollution is to decrease the use of plastic and thereby reducing its production. Degradations and recycling steps followed to diminish these plastic was of no use since it takes abundant stress (mechanical and chemical) to do so and also considered being costly. Biodegradable plastics became major approach to solve this issue and also became eminent since 1970s. From the inventory of biopolymers acting as bioplastics, PHA has gained major importance because of its analogous behavior to that of petro based plastics. PHAs are the linear polymers produced by the microbes to store energy and carbon. Present review discusses about the PHA production method, recent advances in producing, its degradation and applications of PHA which elucidates the gaining importance in today's industrial world.
\end{abstract}

Keywords: Polyhydroxyalkanoates; Bioplastics; Poly-Lactic Acid (PLA); BIOPOL; Polyhydroxybutyrate; PHA depolymerases.

\section{Introduction}

The substance widely used in our clothing, housing, automobiles, packaging, recreation items and medical implants are Plastics, which encompass wide varieties of organic and inorganic elements. Durability being an prime characteristic of them, plastics can be used in various means and thus gaining an importance in our everyday life.

Plastics are the combinations of high molecular weight compounds, called polymers which include polystyrene, polypropylene, polyethylene, polyvinyl chloride and PTFE. Many fossil based plastics are used in industries made of petroleum, nylon, elastomer (natural rubber) etc which releases dioxins when incinerated and thus disposal is a very big problem causing immense risks to the environment (direct or indirect impact on carbon footprint) $[1,2]$ and mankind (accumulation in the food chains). Plastics don't have competence to degrade and thus recycling is done in some cases to reduce this disposal problem but this cannot be the good remedy. Although many new technologies are evolved to make plastic degradable like photodegradable plastics [3], scientists are seeking for better alternative to this so as to resolve this problem and make the substance degradable or have a controlled life time [4].

In response to problems associated with plastic waste and its effect on the environment, there has been considerable interest in the development and production of an alternative, biodegradable plastics or Bioplastics. In the current context of environmental problems, the swop of conventional plastics with bioplastics is a big confront. Also their development became very much essential due to the depletion of petroleum reserves, high oil prices and increased greenhouse gas emissions. Reports also suggested that burning bioplastic will also avoid the problems caused by them breaking down and producing methane, which is 25 times more potent as a greenhouse gas than $\mathrm{CO}_{2}$ [5] and more over this produced methane can be further used as source of energy [6]. Bioplastics are a form of plastics derived from renewable biomass sources, such as vegetable fats and oils, corn starch, pea starch, microbiota and thus do not lead to the depletion of finite resources which shows a good balance between mechanical property and biodegradabailty [7].
Poly-Lactic Acid (PLA) is the early bioplastics, discovered at around 1890. From that day till now, many such different biopolymers have been introduced in the market. The pressures of diminishing resources and increasing waste have lead many professionals to try to re-discover natural polymers and put them to use as materials for manufacture and industry.

Biopolymers can be formed in two ways, those which accumulate and can be collected from the living organisms (microbes and plants) and those which need to be polymerized using renewable resources [8]. Figure 1 describes about the different biopolymer used in routine life coming from different sources [9-12].

Commercially available biopolymers considered as Bioplastics include

- Polyhydroxyalkanoates (PHA)

- $\quad$ Polylactic acid

- Thermoplastic starch

- $\quad$ Bio-polyamides (nylons)

- Bio-polyols

- Cellulosics

Although most of these are produced from different plant and other sources, many of them lack the durability property of the plastic (as packing material) which is a key characteristic considered [13]. Of the all PHA and PLA are having a high demand over other because of its availability and higher potentials to be used as Bioplastics [14].

*Corresponding author: Varsha YM, School of Chemical and Biotechnology, SASTRA University, India, E-mail: varsha_ym@yahoo.com

Received November 02, 2011; Accepted December 12, 2011; Published December 16, 2011

Citation: Varsha YM, Savitha R (2011) Overview on Polyhydroxyalkanoates: A Promising Biopol. J Microbial Biochem Technol 3: 099-105. doi:10.4172/19485948.1000059

Copyright: (c) 2011 Varsha YM, et al. This is an open-access article distributed under the terms of the Creative Commons Attribution License, which permits unrestricted use, distribution, and reproduction in any medium, provided the original author and source are credited 
Citation: Varsha YM, Savitha R (2011) Overview on Polyhydroxyalkanoates: A Promising Biopol. J Microbial Biochem Technol 3: 099-105. doi:10.4172/1948-5948.1000059

\section{Production of bioplastics can be carried out mainly in two ways}

1. Using fermentation techniques

2. By growing plastics in plants (using new genetic engineering techniques)

Fermentation procedures, even though costly are considered best for producing such polymers since they give good outcome within less time [15]. Fermentation carried out by the bacteria may or may not relay on separate polymerization step. This depends on type of substrate which has to be degraded, the microbe which is involving and the conditions which are provided during the process. Some microbes like Ralstonia eutropha [16], Lactobacillus sp. $[17,18]$ have the ability to produce the polymerized substance directly while in case of production of PLA, lactic acid is the outcome of the fermentation which has to be polymerized separately using traditional polymerization process.

Present review gives a note on PHA as Bioplastics, their production process, recent advances involved with the production, PHA degradations, their applications, advantages and disadvantages in using these biopolymers.

\section{Polyhydroxyalkanoates}

Polyhydroxyalkanoates (PHA), natural polyesters of bacteria stored as intracellular inclusions are attractive substitutes for petrochemical plastics because they have analogous material properties to thermoplastics and elastomers [19]. This property of PHA, acting as an ideal storage compound is due to its insolubility inside bacterial cytoplasm, which exerts slight increase in osmotic pressure. Besides serving as storage compounds of carbon and energy sources, PHA also acts as sink for reducing equivalents for some microorganisms. It was reported that the bacteria containing PHA storage materials would be able to survive during starvation period compared to those without PHA, as this energy-reserve material slows down the cell autolysis and its mortality rate [20].

PHAs are composed of R(-)-3-hydroxyalkanoic acid monomers ranging from C3 to C14 carbon atoms with variety of saturated or unsaturated and straight or branched chain containing aliphatic or aromatic side groups. The molecular mass of PHA depends up on the type of growth conditions and microorganism, which may range between $2 \times 10^{5}$ to $3 \times 10^{6}$ daltons. Thus, this property of PHA production, to incorporate monomers of different length made it possible to be used in wide range field of applications. Intracellular depolymerases have the ability to degrade these PHA to carbon and energy source, as soon as the supply of the limiting nutrient is restored [21].

\section{PHA production}

PHA is produced by bacteria under unstable growth conditions. Reports predicted that, some bacteria are capable to produce PHA as much as $90 \%(\mathrm{w} / \mathrm{w})$ of dry cells during depletion of essential nutrients such as nitrogen, phosphorus or magnesium in the medium [22,23]. Polyhydroxybutyrate (PHB), a short-chain length PHAs, was first discovered to be constituent of the bacterium Bacillus megaterium in 1926, by Maurice Lemoigne [14]. Various microbes such as Ralstonia eutropha, Alcaligenes latus, Aeromonas hydrophila, Pseudomonas putida, Recombinant E.coli (having higher success rates) [24] and Bacillus spp.were used for industrial production of PHA [25-28]. In addition to heterotrophic microbes acting as potent PHA producers, several cyanobacteria such as Cholrogloea fritschii, Aphanothece sp., Synechococcus sp., Spirulina platensis have the key enzyme producing PHA $[29,30]$.

The key enzyme producing this PHA is PHA synthases. Figure 2 illustrates about the sequential steps followed by the bacteria in production of PHBs. Carbon derivatives break down to pyruvate through common glycolysis. This pyruvate further forms Acetyl Co-A up on action of pyruvate dehydrogenase, later sequentially forming PHB.

PHA is produced commercially nowadays to meet the requirement of the bioplastic using simple fermentation techniques. Commercial production of PHA as Bioplastics was first conducted by by Zeneca

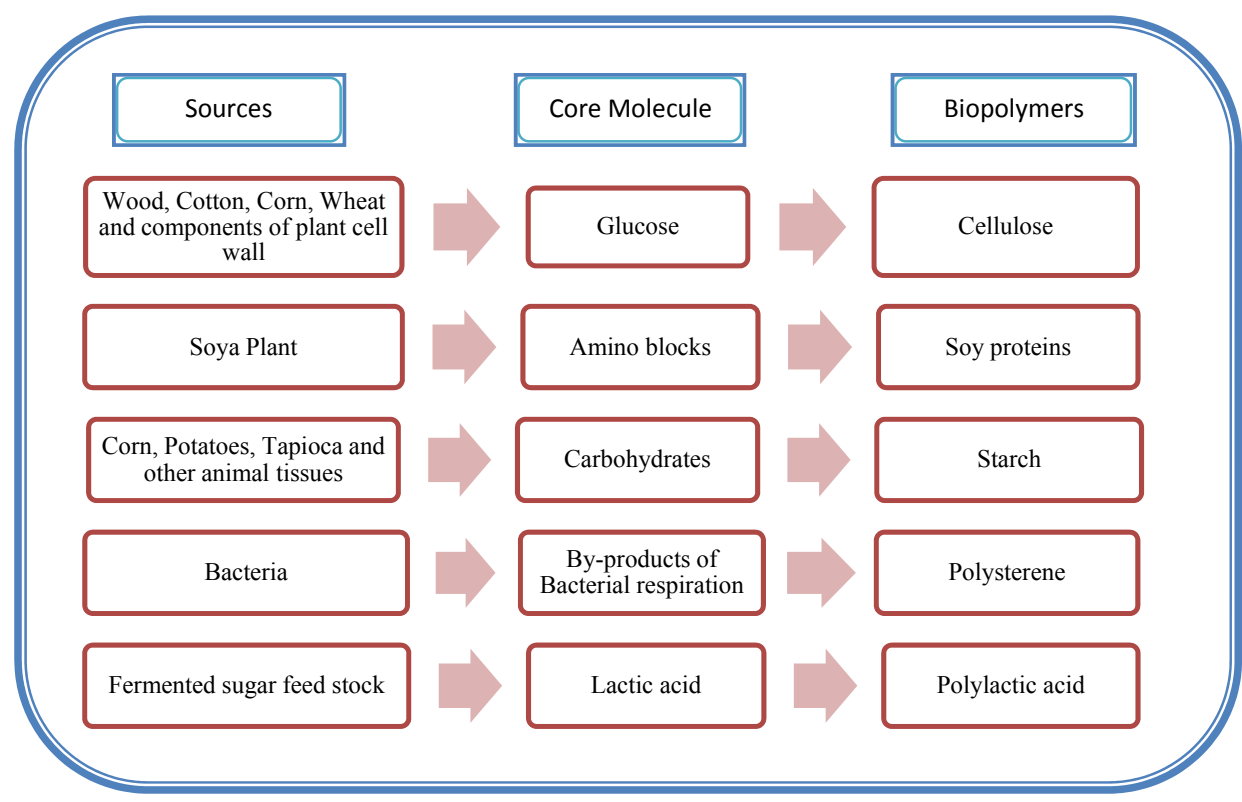

Figure 1: Different sources for the bioplastic production. 
Citation: Varsha YM, Savitha R (2011) Overview on Polyhydroxyalkanoates: A Promising Biopol. J Microbial Biochem Technol 3: 099-105. doi:10.4172/1948-5948.1000059

Bioproducts using Alicaligenes eutrophus [31]. In the 1980s, a glucoseutilizing mutant of Cupriadivus necator was employed by Imperial Chemical Industries (UK) for the industrial production of PHA which was sold under the trade name of Biopol ${ }^{\mathrm{TM}}$ [32]. Industrial production procedures considered various factors [33] for the efficient production of PHA. The factors include culture conditions, type of media required (which usually include complex mixtures of amino acids, vitamins, proteins, lipids, carbohydrates, nucleotides, nucleosides and minerals) $[9,34]$, suitable microbe to be used, type of fermentation process, downstream techniques to get the purified raw form of PHA Bioplastics. Figure 3 give the brief description of all the above factors followed for the industrial production of PHA [35].

Certain organism will only produce the compounds, only when they are starved or limited with certain nutrients like nitrogen in the media [36]. The first type of culture requirement discussed in the Figure 3 , needs limitation of the nutrient source like nitrogen, phosphorous etc. and therefore, PHA accumulation takes place at stationary phase [37], which can be removed easily using activated carbon adsorption, solvent extraction methods $[38,39]$. This may require additional supply of carbon source [40] after depletion of other nutrients in the medium and thus fed batch operations are considered to be suitable [41]. In the other type, PHA being accumulated in log phase requires two-stage fermentation method [35].

By varying the producing strains, substrates and co-substrates, a number of different PHAs can be synthesized which differ in monomer composition. The only problem faced by the PHA production is its cost. Due to specific culture conditions requirements, the procedure still becomes costly and more over the carbon sources used is actually an edible raw material like corn, wheat, potato etc. which goes waste later. Hence improvements and future developments in fermentation/ separation technology will help in bringing the production costs slightly down [42].

New developments in this field helped in bringing down the difference between the petro based plastic and PHA Bioplastics which improved its competitiveness [43]. Scientists have shown immense progress in searching for new bacterial strains, creating new types of recombinant strains and tailoring myriad of PHA to reduce the cost of production. The simplest approach to reduce the cost of production is to choose renewable, inexpensive and most readily available carbon substrates that could support both the microbial growth and PHA production efficiently. Nowadays microbes are isolated from or employed over the effluent wastes, discharges etc which contain polluted and residual matter, so that they can be degraded in an ecofriendly way [44-51]. Reports illustrated that few microbes are capable of producing PHA using carbon sources from complex waste effluents, residual effluents, oil paints [52], alkanes [53], fatty acids etc. Various industrial and food wastes are used as carbon source like malt wastes from a beer brewery plant which is used by Alcaligenes latus [54]. Ralstonai eutropha uses fragmented organic wastes (conversion of organic wastes to short chain volatile fatty acids through hydrolysis and acidogenesis) for PHA production from the food and beverage industries for the PHA production [55].

It is greatness of the scientists and researchers to use the industrial effluents as carbon source for the production of PHA Bioplastics. This is proved by using Pseudomonas putida CA-3 strain against toxic pollutant like styrene, naphthalene used as the sole source of carbon and

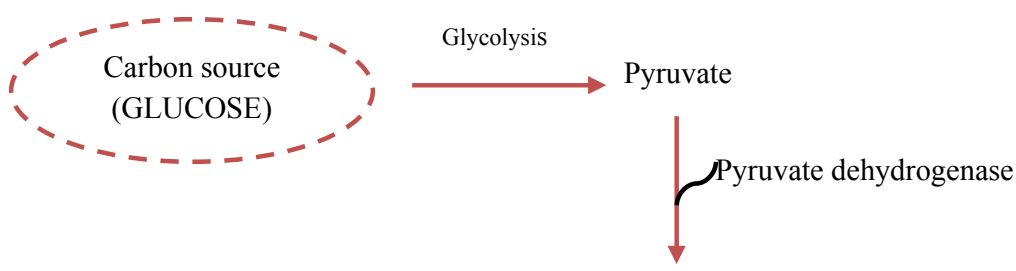

2 Acetyl Co-A

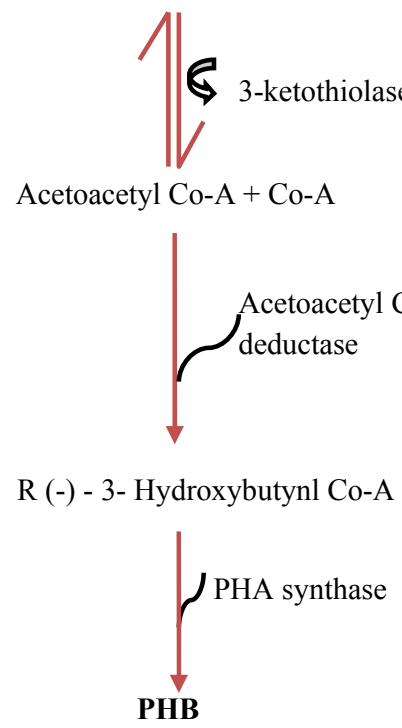

Figure 2: Sequential steps of production of PHB involving PHA synthases. 
Citation: Varsha YM, Savitha R (2011) Overview on Polyhydroxyalkanoates: A Promising Biopol. J Microbial Biochem Technol 3: 099-105. doi:10.4172/1948-5948.1000059

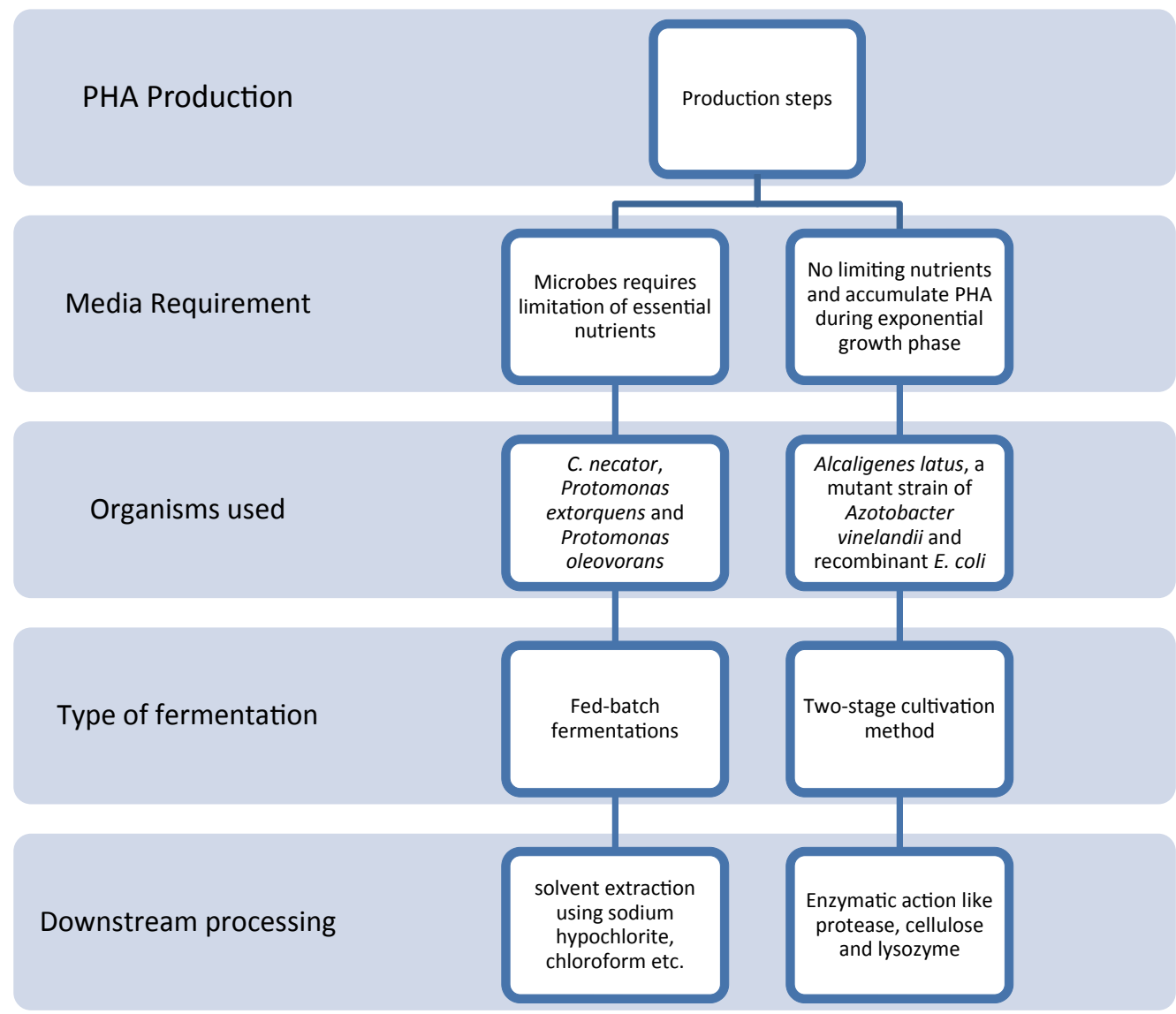

Figure 3: Steps involved in PHA production.

energy for accumulating medium-chain-length polyhydroxyalkanoates (MCL-PHAs) [56-58]. In few cases, mixed cultures (miniature of complex microorganisms) are required for complete polymerization process since the carbon source provided may be in complex form and cannot be degraded so easily [59-61]. To overcome this cost ineffective process, several studies have been made to isolate such microbes which utilize these complex compounds and degrade them giving bioplastics at last. One such example is Saccharophagus degradans (ATCC 43961) which can degrade insoluble cellulose [62] from the textile and dye effluents [63].

Industrial PHA production technology is currently based on bacteria cultivation using pure cultures grown in well-defined nutrient deficient synthetic media with single substrates [64]. Corn plants have high contents of carbon source and thus corn is directly used as substrate, thus the edible part of the plant is getting wasted. Researchers are trying to overcome this problem by incorporating bacterial gene in to the plant which helps in accumulating PHA, using the other parts of plants like roots, leaves, stem etc. People found genetically engineered plants also help to get through several environ problems [65-67]. Also transgenic plants are coming in to limelight in producing PHAs, MIT researchers being first to start it at 1989. It has been reported that PHA are produced in plastids of transgenic plants like Arabidopsis thaliana and Brassica napus. While in few, peroxisomes also serve as storage bags for PHAs [68]. Nicotiana tabacum, Gossypium hirsutum,
Medicago sativa, Elaeis guineensis, Linum usitatissimum are some of the other plants which produces PHAs by transgenic methods [69].

\section{Recent advancements in production of PHAs}

- Mixed microbial cultures are used for the synthesis of biofuels from the waste glycerols [70-73] also produces PHA as the byproduct [74]. Jatropha biodiesel byproducts are used as carbon source by Bacillus sonorensis and Halomonas hydrothermalis for production of PHAs [75].

- Cupriavidus necator organism is reported to produce PHAs from the waste frying oils [76], oil sludge [77] and organic acid wastes from kitchen [78].

- Contaminated oil residues containing polycyclic aromatic hydrocarbons are degraded using Sphingobium scionense sp. WP01, producing PHBs [79].

- Ogunjobi reported that Pseudomonas putrefaciens, an omnipotent species isolated from the poultry wastes when fed with corn cob as carbon source produced PHAs with an yield of $66.67 \% \mathrm{w} / \mathrm{w}$ of cell dry weight [80-82].

- Liquid bean curd waste is used as low cost carbon source by Alcaligenes latus for the production of PHAs [83]. Alcaligenes latus also have capability to degrade hydrocarbons in the same way [84]. 
- Transgenic sugarcane (Saccharum sp.) is used extensively nowadys for production of PHAs [85].

- A new type of PHA containing lactide as a co-monomer is synthesized which is believed to have higher durability [86].

\section{PHA biodegradation}

Biopolymers have the ability to degrade by itself taking sufficient shelf life period. BIOPOL was actually degraded in soil in 4 weeks. Microbial (enzymatic) action on high molecular weight PHA is the only way to degrade these bioplastics in an eco-friendly manner which is done by secreting the PHA depolymerases. Many such bacteria and fungi are widely distributed which have capability of producing these PHA depolymerases. Two different PHA depolymerases exists, extracellular and intracellular. Intracellular PHA depolymerases (i-PHA depolymerases) are released when the required nutrients are supplied back to the medium and actively degrade the endogenously stored native (amorphous) PHA. This is generally of no use, as this work is done by accumulating bacteria itself and that too internally. While extracellular PHA depolymerases (e-PHA depolymerases), are carboxyesterases have capability to hydrolyze the water insoluble PHA to water soluable monomers [87]. These e-PHA depolymerases are composed from the accumulating cells of microbes after death and cell lysis, hence can be separated easily, purified and used extensively for PHA degradations.

Various bacterial and fungal species have been reported which degrades PHA extracellularly such as aerobic and anaerobic PHAdegrading microorganisms isolated from various ecosystems such as soil (Pseudomonas lemoignei), compost, aerobic and anaerobic sewage sludge (Alcaligenes faecalis), fresh (Comamonas testosterone) and marine water (Pseudomonas stutzeri), including deep sea, estuarine sediment, and air. These microbes are separated from the specific sites, treated to excrete e-PHA depolymerases, enzyme is purified and further used for bioplastic degradation. Such biodegradation of polymer essentially depends on the certain conditions like environment temperature, inorganic composition of nutrients etc. [88]. Recent reports have added Gracilibacillus and Enterobacter contributions to degrade PHA Bioplastics [89].

\section{Applications of PHA bioplastics}

Medical applications include development of cardiovascular products, for drug delivery (acting as microparticulate carriers), nerve repair processes, soft tissue repair (tissue engineering), cell implants etc. PHA Bioplastics are used in and as packing films, disposable items (utensils, hygiene products), cosmetic products, in agricultural applications like biodegradable plastic films for crop protection, seed encapsulation etc. [90]. Nowadays these Bioplastics are used as mobile phone casings, for $\mathrm{E}$ - devices, for $\mathrm{CD}$ etc.

\section{Benefits and drawbacks of PHA bioplastics}

PHA Bioplastics are derived using renewable resources through eco-friendly synthesis process and also can be biodegradable and showing sufficient transparency. Besides having such good collection of pros, they have certain disadvantages too like their compostable nature only under specific conditions due to its brittleness, some show dominant hydrophilic character, unsatisfactory mechanical properties particularly under wet environments.

\section{Conclusion}

Plastic usage in the daily routine life has increased its significance and production which actually created problem in the long run. To replace these, biodegradable polymers came in to limelight which are considered as Bioplastics. PHA being one of them is naturally accumulated in the microbes which can be driven out using some simple downstream techniques. This phenomena lead researchers to plant their intellect and commercially produce these PHA bioplastics from different sources like natural residues, waste effluents etc using fermentation technology. The setback of plastic reusage and degradation is also solved by using these PHA bioplastics, since they can be biodegraded easily by the same microbe producing it or by the use of other microbe producing the key enzyme called PHA depolymerases. Although they have certain disadvantages like brittleness in moulding the plastic, because of their wide application range and analogous nature to that of petro based plastics, techniques are still more evolving to overcome these difficulties in handling these bioplastics, considering them to be a promising biopol.

\section{References}

1. Ali Elredaisy SM (2010) Ecological Benefits of Bioremediation of Oi Contaminated Water in Rich Savannah of Palogue, Upper Nile Area-Southern Sudan. J Bioremed Biodegrad 1: 103

2. Ghoodjani E, Bolouri SH (2011) Experimental Study of $\mathrm{CO}_{2}-\mathrm{EOR}$ and N2-EOR with Focus on Relative Permeability Effect. J Pet Environ Biotechnol 2: 106

3. Santhoskumar AU, Palanivelu K, Sharma SK, Nayak SK (2010) Comparison of Biological Activity Transistion Metal 12 Hydroxy oleate on Photodegradation of Plastics. J Bioremed Biodegrad 1: 109

4. Santhoskumar AU, Palanivelu K, Sharma SK, Nayak SK (2010) A New Synthesis of Nickel 12-Hydroxy Oleate Formulation to Improve Polyolefin's Degradation. J Bioremed Biodegrad 1: 108

5. Preeti C, Archana T (2011) Integration of Natural and Biological Sources for the Production of Biopolymer: Actual and Potential Utilization of Various Wastes. J Pharm Res 4: 53-55

6. Padilla-Gasca E, López-López A, Gallardo-Valdez J (2011) Evaluation of Stability Factors in the Anaerobic Treatment of Slaughterhouse Wastewater. J Bioremed Biodegrad 2: 114

7. Guochen Du, Lilian XLC, Jian Yu (2004) High-Efficiency Production of Bioplastics from Biodegradable Organic Solids. J Polym Environ 12: 89-94

8. http://www.nviroplast.com/biopackaging.asp

9. Gayen S, Ghosh U (2011) Pectinmethylesterase Production from mixed agro- wastes by Penicillium notatum NCIM. 923 in Solid-State fermentation. J Bioremed Biodegrad 2: 119

10. Jagannathan S, Vijayakumar R, Rahul Gandhi P, Ananthi M, Charles C, et al. (2010) Analysis of Carbohydrates in Newly Developed Liquid State Rabies Vaccine. J Microbial Biochem Technol 2: 147-151

11. El-Bondkly AM, Aboshosha AAM, Radwan NH, Dora SA (2010) Successive Construction of ß-Glucosidase Hyperproducers of Trichoderma Harzianum Using Microbial Biotechnology Techniques. J Microbial Biochem Technol 2: 70-73

12. Dajanta K, Apichartsrangkoon A, Chukeatirote E (2011) Antioxidant Properties and Total Phenolics of thua nao (a Thai fermented soybean) as Affected by Bacillus-Fermentation. J Microbial Biochem Technol 3: 56-59

13. Lillian Liu (2006) Bioplastics in Food Packaging: Innovative Technologies for Biodegradable Packaging.

14. Chen GQ (2009) A microbial Polyhydroxyalkanoates (PHA) Based Bio- and Materials Industry. Chem Soc Rev 38: 2434-2446

15. Benerji DSN, Ayyanna C, Rajini K, Rao BS, Banerjee DRN, et al. (2010) Studies on Physico-Chemical and Nutritional Parameters for the Production of Ethanol $f$ rom Mahua Flower (Madhuca indica) Using Saccharomyces Cerevisiae - 3090 Through Submerged Fermentation (smf). J Microbial Biochem Technol 2: 4650 
Citation: Varsha YM, Savitha R (2011) Overview on Polyhydroxyalkanoates: A Promising Biopol. J Microbial Biochem Technol 3: 099-105. doi:10.4172/1948-5948.1000059

16. Chakraborty P, Gibbons W, Muthukumarappanl K (2009) Conversion of Volatile Fatty Acids into Polyhydroxyalkanoate by Ralstonia eutropha. J Appl Microbiol 106: 1996-2005

17. de Lima CJB, Coelho LF, da Silva GP, Alvarez G, Contiero J (2010) L(+) Lactic Acid Production by New Lactobacillus Rhamnosus B 103. J Microbial Biochem Technol 2: 64-69

18. Graver MA, Wade JJ (2010) Growth and Acidification by Vaginal Lactobacill in Anaerobic Liquid Medium Over the pH Range 5.5-8.0. J Bacteriol Parasitol 1: 102

19. Choi J, Lee SY (1998) Factors Affecting the Economics of Polyhydroxyalkanoate Production by Bacterial Fermentation. Appl Microbiol Biotechnol 51: 13-21

20. Anderson AJ, Dawes EA (1990) Occurrence, Metabolism, Metabolic Role, and Industrial Uses of Bacterial Polyhydroxyalkanoates. Microbiol Rev 54: 450-472

21. Ojumu TV, Yu J, Solomon BO (2003) Production of Polyhydroxyalkanotes, a Bacterial Biodegradable Polymer. Afr J Biotechnol 3: 18-24

22. Madison LL, Huisman GW (1999) Metabolic Engineering of Poly(3Hydroxyalkanoates): From DNA to Plastic. Microbiol Mol Biol Rev 63: 21-53

23. Chanprateep S (2010) Current Trends in Biodegradable Polyhydroxyalkanoates. J Biosci Bioeng 110: 621-632

24. Soorapaneni S, Apte-Deshpande A, Sabnis-Prasad K, Kumar J, Raiker VA, et al. (2010) Arabinose Promoter Based Expression of Biologically Active Recombinant Human Growth Hormone in E. coli: Strategies for Over Expression and Simple Purification Methods. J Microbial Biochem Technol 2: 38-45

25. Yu PH, Chua H, Huang AL, Ho KP (1999) Conversion of Industrial Food Wastes by Alcaligenes latus into Polyhydroxyalkanoates. Appl Biochem Biotechnol 77 : 445-454

26. Zhang HF, Ma L, Wang ZH, Chen GQ (2009) Biosynthesis and Characterization of 3-hydroxyalkanoate terpolyesters with Adjustable Properties by Aeromonas hydrophila. Biotechnol Bioeng 104: 582-589

27. Mirdamadian SH, Emtiazi G, Golabi MH, Ghanavati H (2010) Biodegradation of Petroleum and Aromatic Hydrocarbons by Bacteria Isolated from PetroleumContaminated Soil. J Pet Environ Biotechnol 1: 102

28. Eremina NS, Yampolskaya TA, Altman IB, Mashko SV, Stoynova NV (2010) Overexpression of ydbK-encoding Putative Pyruvate Synthase Improves L-valine Production and Aerobic Growth on Ethanol Media by an Escherichia coli Strain Carrying an Oxygen-Resistant Alcohol Dehydrogenase. J Microbial Biochem Technol 2: 77-83

29. Yew SP, Jau MH, Yong KH, Abed RMM, Sudesh K (2005) Morphological Studies of Synechocystis sp. UNIWG under Polyhydroxyalkonoate Accumulating Conditions. Malaysian Journal of Microbiology 1: 48-52

30. Bordenave S, Goni-Urriza M, Caumette P, Duran R (2009) Differential Display Analysis of cDNA Involved in Microbial Mats Response after Heavy Fuel Oil Contamination. J Microbial Biochem Technol 1: 1-4

31. Qiang CG, William J (1997) Production of Poly-b-hydroxybutyrate by Azotobacter vinelandii in a Two-Stage Fermentation Process. Biotechnology Techniques 11: 347-350

32. Luzier WD (1992) Materials Derived from Biomass Biodegradable Materials Proc Natl Acad Sci USA 89: 839-842

33. Beshay U, Daba A, Gohar Y (2009) Optimization of Submerged Culture Conditions for Exo-Polysaccharides Production by Streptomyces Nasri-UV 135 In Bioreactor. J Microbial Biochem Technol 1: 43-46

34. Gopalakrishnan KK, Detchanamoorthy S (2011) Effect of Media Sterilization Time on Penicillin G Production and Precursor Utilization in Batch Fermentation. J Bioprocess Biotechniq 1: 105

35. Mendez-Vilas A (2010) Current Research, Technology and Education Topics in Applied Microbiology and Microbial Biotechnology (2010 edn), Formatex Research Center, Badajoz, Spain

36. Gesheva V (2009) Production of Fibrinolytic Enzyme by Streptomyces Rimosus at Conditions of Nitrogen Limitation. J Microbial Biochem Technol 1: 57-58

37. Lakshminarayan H, Rajaram A, Narayanan S (2009) Involvement of Serine
Threonine Protein Kinase, PknL, from Mycobacterium Tuberculosis H37Rv in Starvation Response of Mycobacteria. J Microbial Biochem Technol 1: 30-36

38. Kurnaz SU, Buyukgungor H (2009) Assessment of Various Biomasses in the Removal of Phenol from Aqueous Solutions. J Microbial Biochem Technol 1 $47-50$

39. Kumar NK, Reddy DSR, Venkateswarlu P (2010) Application of Response Surface Methodology for Optimization of Chromium Biosorption from an Aqueous Solution onto Syzigium cumini (java) Seed Powder. J Microbial Biochem Technol 2: 20-27

40. Amin GA (2011) Integrated Two-Stage Process for Biodesulfurization of Model Oil by Vertical Rotating Immobilized Cell Reactor with the Bacterium Rhodococcus erythropolis. J Pet Environ Biotechnol 2: 107

41. da Silva TL, Feijão D, Reis A (2011) Monitoring Rhodotorula glutinis CCMI 145 Stress Physiological Response during Fed-Batch Fermentations Using MultiParameter Flow Cytometry. J Microbial Biochem Technol 3: 6-12

42. Sang YL (1996) Bacterial polyhydroxyalkanoates. Biotechnology and Bioengineering 49: 1-14

43. Porta R, Di Pierro P, Sorrentino A, Mariniello L (2011) Promising Perspectives for Transglutaminase In "Bioplastics" Production. J Biotechnol Biomaterial 1 $102 \mathrm{e}$

44. Kumar KK, Prasad MK, Sarma GVS, Murthy CVR (2009) Removal of Cd (II) from Aqueous Solution Using Immobilized Rhizomucor Tauricus. J Microbia Biochem Technol 1: 15-21

45. Narasimhulu K, Rao PS, Vinod AV (2010) Isolation and Identification of Bacterial Strains and Study of their Resistance to Heavy Metals and Antibiotics. J Microbial Biochem Technol 2: 74-76

46. Gurel L, Senturk L, Bahadir T, Buyukgungor H (2010) Treatment of Nicke Plating Industrial Wastewater by Fungus Immobilized onto Rice Bran. J Microbial Biochem Technol 2: 34-37

47. Elbanna K, Hassan G, Khider M, Mandour R (2010) Safe Biodegradation of Textile Azo Dyes by Newly Isolated Lactic Acid Bacteria and Detection of Plasmids Associated With Degradation. J Bioremed Biodegrad 1: 112

48. Sridevi V, Lakshmi MVVC, Swamy AVN, Rao MN (2011) Implementation of response surface methodology for phenol degradation using Pseudomonas putida (NCIM 2102). J Bioremed Biodegrad 2: 121

49. Sanuth HA, Fagade OE, Ogunjobi AA (2011) Survival Trend of Lead Solubilizing Strains of Pseudomonas Species in Lead Polluted Soil Samples. J Bioremed Biodegrad 2: 123

50. Aghamiri SF, Kabiri K, Emtiazi G (2011) A Novel Approach for Optimization of Crude Oil Bioremediation in Soil by the Taguchi Method. J Pet Environ Biotechnol 2: 108

51. Augusto da Costa AC, da Silva Lino LA, Hannesch O (2011) Total Microbia Populations in Air-Conditioned Spaces of a Scientific Museum: Precautions Related to Biodeterioration of Scientific Collections. J Bioprocess Biotechniq 1: 106

52. Fukui T, Doi Y (1998) Efficient Production of Polyhydroxyalkanoates from Plant Oils by Alcaligenes eutrophus and its Recombinant Strain. Appl Microbio Biotechnol 49: 333-336

53. Lageveen RG, Huisman GW, Preusting H, Ketelaar P, Eggink G, et al. (1988) Formation of Polyesters by Pseudomonas oleovorans: Effect of Substrates on Formation and Composition of Poly-(R)-3-hydroxyalkanoates and Poly-(R)-3hydroxyalkenoates. Appl Environ Microbiol 54: 2924-2932

54. Yu PH, Chua H, Huang AL, Lo W, Chen GQ (1998) Conversion of Food Industrial Wastes into Bioplastics. Appl Biochem Biotechnol 70: 603-614

55. Guochen Du, Lilian XL, Jian Yu (2004) High-Efficiency Production of Bioplastics from Biodegradable Organic Solids. J Polym Environ 12: 89-94

56. Niall DL, Kelvin EC, Patrick W, Miriam G, Alan DWD (2005) Genetic Characterization of Accumulation of Polyhydroxyalkanoate from Styrene in Pseudomonas putida CA-3. Appl Environ Microbiol 71: 4380-4387

57. Shrivastava R, Purohit H, Phale PS (2011) Metabolism and Preferentia 
Citation: Varsha YM, Savitha R (2011) Overview on Polyhydroxyalkanoates: A Promising Biopol. J Microbial Biochem Technol 3: 099-105. doi:10.4172/1948-5948.1000059

Utilization of Phenylacetic acid and 4-Hydroxyphenylacetic Acid in Pseudomonas putida CSV86. J Bioremed Biodegrad 2: 120

58. Poornima K, Karthik L, Swadhini SP, Mythili S, Sathiavelu A (2010) Degradation of Chromium by Using a Novel Strains of Pseudomonas Species. J Microbial Biochem Technol 2: 95-99

59. Jame SA, Rashidul Alam AKM, Fakhruddin ANM, Alam MK (2010) Degradation of Phenol by Mixed Culture of Locally Isolated Pseudomonas Species. J Bioremed Biodegrad 1: 102

60. Maiyappan S, Amalraj ELD, Santhosh A, Peter AJ (2010) Isolation, Evaluation and Formulation of Selected Microbial Consortia for Sustainable Agriculture. J Biofertil Biopestici 2: 109

61. Monica S, Karthik L, Mythili S, Sathiavelu A (2011) Formulation of Effective Microbial Consortia and its Application for Sewage Treatment. J Microbial Biochem Technol 3: 51-55

62. Hungund BS, Gupta SG (2010) Improved Production of Bacterial Cellulose From Gluconacetobacter Persimmonis GH-2. J Microbial Biochem Technol 2: 127-133

63. Luis EAM, Mark R (2008) Utilization of Cellulosic Waste from Tequila Bagasse and Production of Polyhydroxyalkanoate (PHA) Bioplastics by Saccharophagus degradans. Biotechnol Bioeng 100: 882-888

64. Dias JML, Lemos PC, Serafim LS, Oliveira C, Eiroa M, et al. (2006) Recent Advances in Polyhydroxyalkanoate Production by Mixed Aerobic Cultures: From the Substrate to the Final Product. Macromol Biosci 6: 885-906

65. Sonoki T, Kajita S, Uesugi M, Katayama Y, limura Y (2011) Effective Removal of Bisphenol a from Contaminated Areas by Recombinant Plant Producing Lignin Peroxidase. J Pet Environ Biotechnol 2: 105

66. Gai CS, Dini-Andreote F, Andreote FD, Lopes JRS, Araújo WL (2011) Endophytic Bacteria Associated to Sharpshooters (Hemiptera: Cicadellidae), Insect Vectors of Xylella fastidiosa Subsp. pauca. J Plant Pathol Microbiol 2: 108

67. Aberoumand A (2011) Protein, Fat, Calories, Minerals, Phytic acid and Phenolic in Some Plant Foods Based Diet. J Food Process Technol 2: 114

68. Poirier Y (2001) Production of Polyesters in Transgenic Plants. Adv Biochem Eng Biotechnol 71: 209-240

69. Abdul MMY, Ghulam KAP, Chai-Ling H (2008) Trangenic Plants Producing Polyhydroxyalkanoates. Asia Pac J Mol Biol Biotechnol 16: 1-10

70. Zhang B, Shahbazi A (2011) Recent Developments in Pretreatment Technologies for Production of Lignocellulosic Biofuels. J Pet Environ Biotechnol 2: 108

71. Iyovo GD, Du G, Chen J (2010) Sustainable Bioenergy Bioprocessing: Biomethane Production, Digestate as Biofertilizer and as Supplemental Feed in Algae Cultivation to Promote Algae Biofuel Commercialization. J Microbial Biochem Technol 2: 100-106

72. Iyovo GD, Du G, Chen J (2010) Poultry Manure Digestate Enhancement of Chlorella Vulgaris Biomass under Mixotrophic Condition for Biofuel Production. J Microbial Biochem Technol 2: 51-57

73. Imandi SB, Karanam SK, Garapati HR (2010) Optimization of Process Parameters for the Productionof Lipase in Solid State Fermentation by Yarrowia lipolytica from Niger Seed oil Cake (Guizotia Abyssinica). J Microbial Biochem Technol 2: 28-33

74. Przybylek G (2011) Synthesis Of Polyhydroxyalkanates from Waste Glycerol Obtained in the Production of Biodiesel. Polimery 56: 108-113

75. Shrivastav A, Sanjiv KM, Bhumi S, Imran P, Deepti J, et al. (2010) Isolation of Promising Bacterial Strains from Soil and Marine Environment for Polyhydroxyalkanoates (Phas) Production Utilizing Jatropha Biodiesel Byproduct. Int J Biol Macromol 47: 283-287

76. Rob AJV, David JH, Melvin AK, Craig DW, Zofia PS, et al. (2011) Production of Polyhydroxyalkanoates from Waste Frying Oil by Cupriavidus necator. AMB Express 1: 11

77. Lima TMS, Fonseca AF, Leão BA, Mounteer AH, Tótola MR (2011) Oil
Recovery from Fuel Oil Storage Tank Sludge Using Biosurfactants. J Bioremed Biodegrad 2: 125

78. Farah NO, Abdul R, Halimatun SH, Tabassum M, Phang LY, et al. (2011) Utilization of Kitchen Waste for the Production of Green Thermoplastic Polyhydroxybutyrate (PHB) by Cupriavidus necator CCGUG 52238. Afr J Microbiol Res 5: 2873-2879

79. Quanfeng L, Gareth L (2011) Formation of Poly-ß-hydroxybutyrate from Polycyclic Aromatic Hydrocarbons by Sphingobium scionense sp. WP01. International Conference on Computer Distributed Control and Intelligent Environmental Monitoring 2448-2451

80. Ogunjobi AA (2011) Production of Polyhydroxyalkanoates by Pseudomonas Putrefaciens from Cheap and Renewable Carbon Substrates. EJEAFChe 10 2798-2805.

81. St-Onge R, Goyer C, Filion M (2010) Pseudomonas Spp. can Inhibit Streptomyces scabies Growth and Repress the Expression of Genes Involved in Pathogenesis. J Bacteriol Parasitol 1: 101

82. Bouffartigues E, Gicquel G, Bazire A, Fito-Boncompte L, Taupin L, et al (2011) The Major Outer Membrane Protein Oprf is Required for Rhamnolipid Production in Pseudomonas aeruginosa. J Bacteriol Parasitol 2: 118

83. Kumalaningsih, Nur H, Nur Aini (2011) Optimization of Polyhydroxyalkanoates (PHA) Production From Liquid Bean Curd Waste by Alcaligenes latus Bacteria J Agric Food Tech 1: 63-67

84. Pathak H, Bhatnagar K (2011) Alcaligenes-The 4T Engine Oil Degrader. J Bioremed Biodegrad 2: 124

85. Kimberley T, Leigh G (2011) Peroxisomal Polyhydroxyalkanoate Biosynthesis is a Promising Strategy for Bioplastic Production in High Biomass Crops. Plant Biotechnol J 9: 958-969

86. Taguchi S, Yamada M, Matsumoto K, Tajima K, Satoh Y, et al. (2008) A Microbial Factory for Lactate-Based Polyesters using a Lactate-Polymerizing Enzyme. PNAS 105: 17323- 17327

87. Jendrossek D, Handrick R (2002) Microbial Degradation of Polyhydroxyalkanoates. Annu Rev Microbiol 56: 403-32

88. Jendrossek D (2005) Extracellular Polyhydroxyalkanoate (PHA) Depolymerases: The Key Enzymes of PHA Degradation. Biopolymers 3b: 41-83

89. Volova TG, Boyandin AN, Vasil'ev AD, Karpov VA, Kozhevnikov IV, et al (2011) Biodegradation of polyhydroxyalkanoates (PHAs) in the South China Sea and identification of PHA-degrading bacteria. Microbiology 80: 252-260

90. Anushri S, Archana T (2011) Polyhydroxyalkonates: Green Plastics of the Future. International Journal of Biomedical and Advance Research 2: 356-367. 